\title{
Article \\ What Is Important for the Growth of Latecomers in the Medical Device Industry?
}

\author{
Kyungtae Yeom ${ }^{1}$, Changhyeon Song ${ }^{2, * \mathbb{D}}$, Kwangsoo Shin ${ }^{1, *}$ and Ho Seon Choi ${ }^{3}$ \\ 1 Department of Biomedical Convergence, College of Medicine, Chungbuk National University, \\ Chungdae-ro 1, Seowon-gu, Cheong-ju, Chungbuk 28644, Korea; gilbertkt@gmail.com \\ 2 Strategic Planning Team, Korea Institute of Science and Technology, 5, Hwarang-ro 14-gil, \\ Seoungbuk-gu, Seoul 02792, Korea \\ 3 AI \& Contents Department, Korea Enterprise Data, Uisadang-daero 21, Yeoungdeungpo-gu, \\ Seoul 07237, Korea; hschoi@kedkorea.com \\ * Correspondence: ch.song@kist.re.kr (C.S.); sksidea@chungbuk.ac.kr (K.S.)
}

Citation: Yeom, K.; Song, C.; Shin, K.; Choi, H.S. What Is Important for the Growth of Latecomers in the Medical Device Industry?. J. Open Innov. Technol. Mark. Complex. 2021, 7, 13. https://doi.org/10.3390/joitmc 7010013

Received: 26 November 2020 Accepted: 30 December 2020 Published: 5 January 2021

Publisher's Note: MDPI stays neutral with regard to jurisdictional clai$\mathrm{ms}$ in published maps and institutional affiliations.

Copyright: $(2021$ by the authors. Licensee MDPI, Basel, Switzerland. This article is an open access article distributed under the terms and conditions of the Creative Commons Attribution (CC BY) license (https:// creativecommons.org/licenses/by/ $4.0 /)$.

\begin{abstract}
In the medical device industry, which is highly value-added and requires multidisciplinary knowledge, major global firms dominate the market, so it is necessary to establish a growth strategy suitable for latecomers. Through a Korean case, it was confirmed that import, diversification, and R\&D activity are distinguishing strategies. The existing literature covers these strategies, but these findings are fragmented and differ from those of latecomers. This study examined the impact of the above factors on corporate growth, based on data of 440 Korean medical device manufacturers from 2011 to 2016 . According to the results of panel data regression, diversification and $R \& D$ activity have a positive effect on the financial performance of a firm, while the import business model shows a negative effect. These results are expected to provide implications with respect to strategies for the growth of latecomers in the medical device industry. In future research, it is necessary to investigate how detailed strategies in accordance with the growth stages of a firm can be established.
\end{abstract}

Keywords: latecomer; medical device industry; import business model; diversification; R\&D activity

\section{Introduction}

The medical device industry is characterized by active R\&D investment and a rapid pace of technological innovation [1,2]. However, in this industry, it takes a long time to launch new products, and there are always regulatory issues due to safety and validity [3,4]. Despite these constraints, some advanced countries such as the US, Germany, and Japan have recognized this industry as a high value-added industry and have provided government's financial and institutional support [5]. As proof of this, more patents are issued every year in the medical device field in Europe than in computer, IT communications, and pharmaceutical fields [6,7].

Korea is classified as a latecomer in the medical device industry. First of all, in terms of market size, Korea is ranked 9th in the world after Italy and Canada. In 2018, the US was the overwhelming leader with $42 \%$, while Germany and Japan formed the next group. There is a slight gap between the other countries in the top 10 [8]. Therefore, Korea can be considered as followers. In addition, other related industries close to medical devices are well developed in Korea. These adjacent fields such as ICT and pharmaceuticals are expected to create synergy with the medical device industry. As this indicates, the recent growth rate of the Korean medical device industry is faster than the global average. From 2014 to 2018 , the average annual growth rate of the global medical device market was $4.0 \%$ while the Korean market grew by $8.0 \%$ [9]. However, the lack of a global leading firm is considered as a major weakness. Most Korean medical device firms are small- and mediumsized enterprises (SMEs), and they are not actively entering the global market. Given these 
points, it can be summarized that the Korean medical device industry has sufficient growth potential but is still in a position to catch up to the global leading countries. Although the gap with the leading group is still remarkable, it is expected that the gap will be narrowed in the future due to the influence of growth strategies so far. The medical device industry in latecomer countries is relatively less developed in industrial ecosystem, R\&D investment, infrastructure, etc. As a representative latecomer country in the medical device industry, the Korean case is expected to serve as a guide to other latecomer countries.

Most studies on the medical device industry have been conducted from the perspective of advanced countries, rather than from latecomer countries such as Korea. However, by reviewing cases of Korean medical device firms, we were able to discover features that have not been revealed in previous studies. There have been many cases that have started as a manufacturing business and have then expanded to the import business, or vice versa. In addition, many firms constantly pursue business diversification based on existing technologies. What is worth noting is the fact that even the firms in unrelated industries often enter the medical device industry through diversification. Indeed, from 2011 to 2016, the import volume of medical devices in Korea increased by about $6 \%$ each year on average, and the number of medical device products approved by the Ministry of Food and Drug Safety (MFDS) increased from 9086 to 14,071 [9]. Drastic R\&D investment and tangible research achievement comparable to global leading firms are also noteworthy. As of 2018, patent applications in the medical device field increased by $6.82 \%$ each year on average over the past 10 years, more than five times higher than that of all other industries [9]. Unfortunately, few studies have dealt with these issues from a latecomer perspective. Therefore, it is necessary to explore the growth strategies of latecomers and examine the impact of these strategies on performance through the case of the Korean medical device industry. The results of this study are expected to provide valuable implications for government officials and SMEs in other latecomer countries.

There are existing studies on the growth strategies of latecomers mentioned above: import business models, business diversification, and R\&D activity. By proceeding with imports, manufacturing firms can imitate and apply them to the development of their own products. This leads to improved productivity; as a result, selling imported products leads to corporate growth $[10,11]$. Importing high-tech products from global firms can be seen as an effective business model that can keep up with their advanced technologies at low cost [12]. Medical devices, meanwhile, are known to be suitable for diversification, as there are many products that are produced on a small-quantity batch basis [13]. Product diversification leads to increased revenue by enabling firms to utilize the economies of scope from a resource-based view [14]. In addition, there are empirical results showing that diversification is advantageous for attracting investments because it more widely uses funds from internal and external capital markets [15]. There are numerous studies showing that investing in R\&D generally has a positive effect on a firm's financial performance. In particular, medical devices require multiple disciplines in a single product and tend to be highly dependent on patents [13]. In recent years, the importance of $R \& D$ is more emphasized as more products are developed through joint research between clinicians and firms [1,2].

This paper is structured as follows. Section 2 presents a literature review related to the impact of income, business diversification, and $R \& D$ strategies on sales from the perspective of latecomers. Based on these, several hypotheses are presented. Methodology and variables are explained in Section 3, and results are presented in Section 4. Lastly, Section 5 presents the implications of this study and directions for future research.

\section{Research Background and Hypotheses}

\subsection{General Features and the Current Status of the Korean Medical Device Industy}

The general features of the medical device industry are known as follows. The product life cycle of medical devices tends to be short, so continuous improvement of the product is required and the optimal period for replacement is within $5-10$ years in general $[1,16,17]$. 
As such, the medical device industry has a relatively fast pace of innovation compared to other industries. These features are due to the fact that the medical device industry is knowledge-intensive with active investment in $R \& D[2,3]$. On the other hand, this industry is highly regulated due to safety and validity issues. As with the pharmaceutical industry, product approval is much more challenging because it is directly connected to human life [3]. Numerous products are developed every year, but only a few are approved by regulatory agencies such as the Food and Drug Administration (FDA). Consumers of medical devices are also different from other industries. As medical devices are mainly used by professional medical personnel such as doctors, nurses, and medical technicians, the purchase of medical device products is closely related to their preferences [2]. The role of medical personnel is also important in the product development process. They not only provide ideas at an early stage, but also participate in product testing and feedback processes. By sharing various clinical information with firms, these can be reflected in the design of the final product [1]. In recent years, mobile medical device applications using smartphones have been emerging, and this phenomenon is expected to accelerate further [18].

In the case of Korea, the medical services are known worldwide for its excellent quality. Along with the Korean government's response to COVID-19, the advanced medical system received great attention [19]. In addition, Korea is at a world-class level in various fields of medical service such as high-quality medical personnel, hospital information systems (HISs), and health insurance systems [20]. However, the competitiveness of the medical device industry has not reached that level.

The Korean medical device industry is mostly composed of small- and mediumsized enterprises (SMEs), while the market is occupied by global medical device firms. The medical device market in Korea is largely composed of three groups. Multinational corporations with accumulated R\&D capabilities and infrastructure are monopolizing high-tech, high-priced medical devices such as CT and MRI, mainly in large hospitals in Korea. Next, medium and large domestic corporations are increasing their market share by equipping core technologies in such fields as ultrasound imaging devices, dental CT, and in vitro diagnostic reagents. The remaining $90 \%$ of SMEs produce low- and mid-priced medical devices [9].

Compared to global or large corporations, SMEs do not have many resources to invest in $R \& D$ and have difficulty securing key $R \& D$ personnel [20]. Furthermore, due to the fact that they are relative latecomers, the brand power is weak, so it is often difficult to attract investment [21]. This tendency is clearer in the high-tech medical device market, where a rigorous approval process exists. Moreover, as global firms have increasingly entered the medical device industry through business diversification strategies such as M\&A(Mergers and Acquisitions), it is getting more difficult for SMEs to grow in the market. The advancement of emerging countries such as China is also a threat to the majority of latecomers. Therefore, in order for latecomers to survive and grow in such a competitive environment, strategies from different points of view are required.

\subsection{Growth Strategies and Financial Performance of Latecomers in the Medical Device Industry}

\subsubsection{Import Business Model}

There are various discussions on business models that are emphasized for sustainable growth. In general, a business model refers to a strategy that provides differentiated services in consideration of the value of customers and ensures a continued competitive advantage by preventing competitors from imitating [22,23]. However, from the latecomer's point of view, it is more appropriate to understand this conception as a strategy to investigate the current market environment and seek ways to survive in that. In that sense, the import business model can be an alternative for latecomers.

Latecomers, which are mostly SMEs in following countries, have limitations in growing only with internal resources. They can increase sales by introducing advanced technologies from global leading firms and incorporating them into their own products or by importing 
and selling them. In this way, the import of products through international trade can lead not only to spillovers of technologies but also to increased productivity of beneficiaries [24,25]. This is partly due to the mutual exchange of knowledge about the production process, design process, and market environment [11]. Through reverse engineering, latecomer firms can obtain opportunities to accumulate technical know-how by imitating and upgrading the imported products [26,27]. Increased productivity due to acquired technology and shared knowledge leads to improved corporate profitability [11,12].

The import of foreign medical devices can be a business model because it benefits global firms that export them as well. As hospitals are demanding customers and it is difficult to establish separate distribution networks, global firms prefer to use local firms to supply their products. In particular, this strategy is attractive when entering markets of countries that are physically and culturally distant [28]. Global firms also offer a variety of economic rewards such as additional discounts and incentives to help local firms sell their products $[29,30]$. As local firms can take the gap between the imported price and the final price as operating profit, these benefits lead to increased profitability.

Surely, there is an obvious limit to growing enough through import model. Especially when the imported goods are supplied by a single vendor, it is expected that generating revenue through the import model will be more difficult. Nevertheless, the import-driven business model can be a foundation for the early growth for latecomer firms. If an import strategy is implemented with manufacturing business, firms can expect additional technological advancement. Therefore, it is assumed that the import business model will have a positive effect on sales for latecomers such as Korean medical device SMEs.

Hypothesis 1. The import business model of latecomers in the medical device industry has a positive effect on their financial performance.

\subsubsection{Business Diversification}

Business diversification means that a firm or business unit is branched out into different fields [31]. This strategy is one of the ways that firms can maintain a competitive advantage and improve profitability. The firm can grow by expanding the existing production facilities while maintaining product composition, or by entering relevant fields and changing the product composition [32]. Additionally, diversification can be achieved through a variety of approaches, including internal development, joint ventures, license agreements, mergers, and acquisitions [33].

Why adopt the firm diversification strategy? If a firm concentrates on a single product, it may increase its profits, but it also may increase risk. Furthermore, it is difficult to spread risk from the business cycle [34]. On the other hand, diversification can hedge against overall risk by increasing the diversity of a firm's business portfolio [35]. For SMEs, which are relatively vulnerable to risk, this strategy is even more attractive. Risk mitigation is not the only reason for diversification. When a firm produces a large number of highly relevant products simultaneously, economies of scope can be achieved $[14,36]$. In other words, it refers to the economic effect that is obtained by reducing production costs by jointly utilizing factors that are input in the production process in various fields [15]. This can be a proper strategy for latecomers who need to maximize profits through the efficient use of resources.

However, a diversification strategy may also reduce corporate value. In a diversified firm, business units with poor performance are sustained by surplus from better performing ones [37]. As the degree of diversification increases, there is a possibility that dependence on core business will also increase. This polarization can worsen profitability as a whole [38]. Latecomer firms should also be aware that diversification can be an inefficient strategy unless there is a synergistic effect between diversified businesses.

Diversification can be classified into two types according to the degree of relevance to existing businesses: related and unrelated diversification. Related diversification means expansion to existing business lines or expansion within a firm's main product line, whereas 
unrelated diversification means expansion to industries that are heterogeneous from existing business lines or external expansion [39]. Related diversification has the effect of using the economies of scope and creating synergies related to the efficiency of business operations, as there is a component of the value chain of the common denominator of human and physical resources between existing and new businesses. On the other hand, unrelated diversification has the effect of reducing risk variance or financial risk because it can efficiently distribute capital in the financial internal market [40]. Innovative firms can engage in related diversification by utilizing or improving existing knowledge and skills, or explore entirely new knowledge and skills to create innovative products through unrelated diversification [41].

Empirical results of several studies on the diversification strategy are mixed. The effects of related diversification and unrelated diversification are slightly different for each industry and country $[15,42]$. However, according to recent literature dealing with latecomer cases in the medical device industry, it can be seen that a diversification strategy is conducive to early growth. Malaysia is a latecomer in the medical device industry, and it has been growing rapidly in recent years. Firms producing latex rubber tried to diversify their business into disposable kits and transfusion tubes, starting with surgical gloves [43]. These firms initially started out as subcontractors of global firms, but they managed to grow with appropriate diversification strategies. In Korea, there are also many SMEs that produce multiple products rather than mass-producing one or two products [20]. However, there are still few studies on the impact of diversification strategies on corporate performance in the medical device industry from a latecomer perspective. Therefore, this study proposes the following hypotheses that the related and unrelated diversification strategies will have a positive effect on the sales of latecomer medical device SMEs.

Hypothesis 2-1. The related diversification of latecomers in the medical device industry has a positive effect on their financial performance.

Hypothesis 2-2. The unrelated diversification of latecomers in the medical device industry has a positive effect on their financial performance.

\subsubsection{R\&D Activity}

Technological innovation has become an important factor in determining corporate growth, survival, and competitive advantage [44]. This innovation is made possible by constant investment in R\&D as input and patent application as output [45]. In particular, the medical device industry is highly dependent on technological innovation as technology convergence increases. However, most latecomer firms are SMEs that do not have cuttingedge technology. To close a technological gap with first movers, latecomer firms should continuously invest in $\mathrm{R} \& \mathrm{D}$, protect technology with patents, and launch new products.

R\&D investment is the most common and important activity for the acquisition of technologies. Although it is slow compared to acquiring technology through licensing or M\&A, the technological capability accumulated through R\&D investment can give a continuous competitive advantage [46]. It is essential to build technological competence in order to use the acquired technologies more broadly and further improve them. In order to overcome the challenges of increasingly shorter product life cycle and intensifying competition, SMEs that lack technological capabilities need to increase their investment in R\&D despite insufficient resources [47,48]. However, intensive R\&D investment can threaten the financial stability of a firm. Since the output of R\&D investment do not appear shortly, it is necessary to invest continuously for a long time [49]. In addition, uncertainties of investment output and disagreements over decision making between executives and investors are considered risks of R\&D investment [50]. Nevertheless, intensive R\&D activity remains an indispensable option for latecomer firms. As long as the link between R\&D, technological innovation, and corporate growth is valid, there is no way to grow in the long run except for $R \& D$ investment. 
The intensity of R\&D in the medical device industry is usually higher than that of other industries because knowledge in various fields such as electrical and electronic, machinery, materials, and clinical medicine is required in the entire process from product design, development, and the production of medical devices $[6,16]$. Additional R\&D is frequently required until the final product launch due to various regulations and demanding consumers [4]. In recent years, joint research between clinicians and medical device firms is becoming more active. As clinicians demand improvements in existing products and share innovative ideas with firms, more effective new product development is possible $[1,2]$. Moreover, translational research such as bench to bedside or bedside to bench is gradually increasing [51]. Based on the above, the hypothesis that R\&D investment will lead to financial performance from the latecomer's point of view can be presented.

Hypothesis 3-1. The RED investment of latecomers in the medical device industry has a positive effect on their financial performance.

Patents, the output of R\&D investment, are an important factor for technological innovation. The basic role of patents is to give inventors the privilege of protecting technology, thereby preventing competitors from imitating it and allowing them to have exclusive rights for a limited period of time [52,53]. For latecomers, patents serve as a minimum protection in markets dominated by large and global firms. They prepare for other innovations while protecting their developed technologies. This exclusive right based on patents also enables a faster investment return [54]. In addition, in order for SMEs to actively apply for patents, it requires the constant monitoring and detailed analysis of existing technologies. These activities also help firms establish proper strategies for technological innovation and lead to more influential patent applications [53].

The unique feature of patent activities in the medical device industry is the active participation of clinicians. The interaction between firms, hospitals, and clinicians is important in the development stage, and cooperation with clinicians plays an important role in the patent application stage [55]. In medical device patents granted by the U.S. Patent and Trademark Office, clinicians either are the main inventor or, in 1 of 5 cases, participate. Patents with clinicians showed more citations than those with corporations [1,2]. Like Hypothesis 3-1, patent activity, a result of R\&D activity, is also expected to have a positive effect on latecomers' financial performance.

Hypothesis 3-2. The number of patent applications of latecomers in the medical device industry has a positive effect on their financial performance.

The research model that synthesizes the above hypotheses is shown in Figure 1.



Figure 1. Schematic diagram of research model. 


\section{Method}

\subsection{Data}

The data used in this study were taken from the database of medical device firms and product information registered with the MFDS. From 1956 to 31 December 2016, 5526 firms received manufacturing approvals from MFDS. Among them, firms that underwent business closures or permission cancellations or that presented an absence of corporate information were excluded; only 1025 medical device manufacturers from 2011 to 2016 with firm information and financial status were extracted. The financial information of each firm was obtained from Korea Enterprise Data. Considering the firm's growth and technological innovation capabilities, a total of 440 samples were selected for firms with sales, R\&D investment costs, and patent applications. There were 144 importing firms, 284 related diversification firms, 83 unrelated diversification firms, and 50 listed firms. Table 1 is a classification table for this, and Table 2 describes the distribution of firms by age and the number of employees.

Table 1. Classification table of firms.

\begin{tabular}{cccc}
\hline Import & Related Diversification & Unrelated Diversification & Listed Firms \\
\hline 144 & 284 & 83 & 50 \\
\hline
\end{tabular}

Table 2. Distribution of firms by the age and the number of employees.

\begin{tabular}{cccc}
\hline Age & $\boldsymbol{n}$ & Number of Employees & $\boldsymbol{n}$ \\
\hline 4 years or younger & 6 & 9 or fewer people & 49 \\
5-9 years & 94 & $10-19$ people & 95 \\
10-19 years & 246 & $20-49$ people & 146 \\
20-29 years & 70 & $50-99$ people & 70 \\
30 years or more & 24 & 100-199 people & 45 \\
& & 200 people or more & 35 \\
\hline Sum & 440 & Sum & 440 \\
\hline
\end{tabular}

\subsection{Variable}

\subsubsection{Dependent Variables}

Methods for measuring a firm's performance include return on assets (ROA), return on equity (ROE), total asset growth rate, net sales growth rate, and sales. This study uses sales as dependent variables, and investigates how a firm's import parallels, related diversification, unrelated diversification, $R \& D$ investment costs, and the number of patent applications affect sales. Sales is revenue generated during the transaction process of supplying products or services. Sales are often used to evaluate the impact of R\&D investment as a growth indicator of the profitability of a firm, and the statistical correlation between financial performance indicators and growth indicators is high [56]. In this study, panel regression analysis was performed to analyze the correlation with each independent variable with sales from 2011 to 2016.

\subsubsection{Independent Variables}

In order to explain Hypothesis 1 in this study, we wanted to confirm how it affects sales by using import as an independent variable. Imports can lower a firm's production costs, reduce $R \& D$ investment in manufacturing, and increase output, which in turn can affect sales [11,12]. Among medical device manufacturers, firms that import are given a dummy variable of 1 , while those that do not import are given a dummy variable of 0 , which allows for analysis of the correlation between imports and sales from 2011 to 2016. The target firm was selected as a firm that has obtained permission to engage in the importing business of medical devices from the MFDS, products only applicable to medical devices and not products imported from other industries. 
The Korean medical device industry consists of many diversified firms that produce small quantities of many varieties. Hypothesis 2 deals with the impact of related and unrelated diversification. It was analyzed using a dummy variable of 1 in the case of diversification and 0 in the case of non-diversification. The diversification products associated with electrical and electronic medical devices are various types of medical devices (medical instruments, medical supplies, dental materials, and in-vitro diagnostic reagents) defined by the MFDS classification system, or general electrical and electronic products with similar characteristics to those medical devices. Unrelated diversification is a non-medical device or an unrelated electronic product classified according to the criteria defined by KSIC (Korean Standard Industrial Classification).

In order to confirm whether the R\&D intensity of Hypothesis 3-1 has a positive effect on the sales of a firm, the R\&D investment cost was used as a variable in this study. $R \& D$ investment cost has been used as an independent variable, which has been shown to positively affects sales [57]. The R\&D intensity can be measured as the R\&D investment ratio or the $R \& D$ investment cost. In this study, the $R \& D$ investment cost was used as the independent variable, and the natural log was used. After the R\&D investment, the time lag was set to 4 years, since it took a certain amount of time to show the results. In order to confirm Hypothesis 3-2, we secured the number of patents provided by KIPO (Korean Intellectual Property Office) from 2011 to 2016 for each firm. When evaluating technological innovation capabilities, the number of patents that are typically filed is used. Patents are often used as a variable to confirm whether they contribute to the performance of intellectual property protection [52] or influence corporate performance [53]. Patents have a direct impact on a firm's performance, such as profitability and productivity, are widely used to measure technological innovation performance, and are viewed as a result of R\&D investment activities [58].

\subsubsection{Control Variables}

In this study, the number of employees, the firm age, and the listing status of a firm were used as control variables. The size of a firm is mainly used to measure the various performances of a firm, and assets, sales, the number of employees, the added value, or the profit are usually used to indicate the size of a firm. The larger the size of the firm, the more the shortcomings of small organizations can be overcome and the more profitability increases, which is a factor affecting the performance of the firm [59]. This study measured the number of employees using the size of a firm as a control variable.

The age of a firm is an indicator of experience, and the higher the age of the firm, the more resources, technology, and know-how it has, so it can affect the innovative performance of the firm. It is said that the age of the firm is related to the ratio of safety, activity, and profitability of the firm, and it affects the future predicted value, operation management, and management performance [60]. In general, it is said that, as the age of a firm increases, the survival rate increases [61]. Therefore, the age of the firm was taken as a control variable in this study.

Listed firms are generally evaluated for their technological capabilities and growth potential. In addition, those firms can attract external investment funds through initial public offering. Firms that are larger than SMEs were found to have a positive impact on capital structure, as they had a greater influence on external financing procurement [62]. Therefore, whether a firm is listed or not was included as a control variable. Since the timing of the listing was different for each firm, it was applied considering the year of listing and the year of abolition.

In a study that analyzes the causal relationship between a firm's sales and strategic behaviors such as income business, diversification, and technological innovation, endogeneity may exist. In particular, the endogeneity problem of the relationship between sales and R\&D investment has been an issue in many studies [63-65]. Therefore, time-lag was introduced to a variable related to $R \& D$ investment in consideration of such endogeneity problem. In addition, by controlling the size of a firm measured by the number of em- 
ployees, we tried to minimize the bias which might be caused by endogeneity problem. Detailed composition and operational definitions of variables are described in Table 3.

Table 3. Operational definition of variables.

\begin{tabular}{|c|c|c|}
\hline Classification & Variable & Definition \\
\hline Dependent variable & Sales & Total sales of domestic manufacturing and import \\
\hline \multirow{5}{*}{ Independent variable } & Import & 1 if medical device import, 0 otherwise \\
\hline & Rel_Div & 1 if related diversification, 0 otherwise \\
\hline & Unrel_Div & 1 if unrelated diversification, 0 otherwise \\
\hline & Rnd & Costs used for R\&D investment from 2011 to 2016 , time lag (n-4) \\
\hline & Pnd_dt & Number of patent applications from 2011 to 2016 \\
\hline \multirow{3}{*}{ Control variables } & Size & Total number of employees \\
\hline & Age & Number of years since founding (2016-Year of foundation) \\
\hline & Listed & 1 if firms are listed in the stock market, 0 otherwise \\
\hline
\end{tabular}

\subsection{Analytic Model}

This study collected data from 2011 to 2016 and conducted panel regression analysis. The panel controls the problem of invisible heterogeneity between variables, and reduces bias in the omitted variables [15]. Regression analysis of independent variables with high correlation creates a multicollinearity problem, but we were able to obtain more information by combining 2640 cross-sectional data and time series data through panel analysis and the problem of multicollinearity among variables was solved.

Therefore, the final analytical model is as follows:

$Y_{i t}=\beta_{0}+\beta_{1} \cdot$ Import $_{i t}+\beta_{2} \cdot$ Rel_Div $_{i t}+\beta_{3} \cdot$ Unrel_Div $_{i t}+\beta_{4} \cdot \ln \left(\right.$ Rnd $\left._{i t-4}\right)+\beta_{5} \cdot$ Pnd_dt $_{i t}+\beta_{6} \cdot \operatorname{Size}_{i t}+\beta_{7} \cdot$ Age $_{i t}+\beta_{8} \cdot$ Listed $_{i t}+\varepsilon$

\section{Results and Discussion}

Table 4 describes the basic statistics and correlations that indicate the mean and standard deviation of each variable. Table 4 describes the results of regression analysis between sales and variables.

Table 4. Descriptive statistics and correlations.

\begin{tabular}{|c|c|c|c|c|c|c|c|c|c|}
\hline Variable & Sales & Import & Rel_Div & Unrel_Div & $\ln \left(R n d_{\text {lag }}\right)$ & $P n d \_d t$ & Size & Age & Listed \\
\hline Sales & 1 & & & & & & & & \\
\hline Import & $0.07^{* * *}$ & 1 & & & & & & & \\
\hline Rel_Div & 0.04 * & $0.33^{* * *}$ & 1 & & & & & & \\
\hline Unrel_Div & -0.02 & $-0.23^{* * *}$ & $-0.65^{* * *}$ & 1 & & & & & \\
\hline $\ln \left(\operatorname{Rnd}_{\text {lag }}\right)$ & $0.19^{* * *}$ & $0.11^{* * *}$ & $0.06^{* *}$ & -0.03 & 1 & & & & \\
\hline$P n d \_d t$ & $0.98^{* * *}$ & $0.07^{* * *}$ & 0.04 * & -0.02 & $0.18^{* * *}$ & 1 & & & \\
\hline Size & $1.00^{* * *}$ & $0.07^{* * *}$ & 0.04 * & -0.03 & $0.19^{* * *}$ & $0.97 * * *$ & 1 & & \\
\hline Age & $0.19^{* * *}$ & $0.14^{* * *}$ & -0.02 & $0.11^{* * *}$ & $0.13^{* * *}$ & $0.18^{* * *}$ & $0.19^{* * *}$ & 1 & \\
\hline Listed & $0.16^{* * *}$ & $0.08^{* * *}$ & $0.08^{* * *}$ & $-0.10^{* * *}$ & $0.18^{* * *}$ & $0.16^{* * *}$ & $0.17^{* * *}$ & $0.23^{* * *}$ & 1 \\
\hline Mean & $3.32 \times 10^{8}$ & 0.33 & 0.65 & 0.19 & 12.64 & 15.03 & 294.73 & 13.05 & 0.09 \\
\hline S.D. & $6.58 \times 10^{9}$ & 0.47 & 0.48 & 0.39 & 1.73 & 273.80 & 4691.84 & 8.08 & 0.28 \\
\hline
\end{tabular}

$* * *<0.01,{ }^{* *} p<0.05, * p<0.1$.

Looking at the relationship between the independent variable and the dependent variable, first, the import strategy of a medical device firm had a negative effect on its sales $(p<0.01$; Hypothesis 1 rejected). Although the firm's import strategy is said to increase productivity and eventually increase profitability [11,12], the results of Hypothesis 1 do not support this. These results are assumed to be due to the fact that the data used for the analysis are limited to Korean manufacturers. Global firms that do not manufacture in 
Korea or those that specialize only in imports treat high-tech and high-priced products. On the other hand, the products treated by Korean domestic manufacturers who import simultaneously are generally inexpensive. Therefore, it is expected that their import behavior did not have significant impact on sales. Domestic manufacturers may be less competitive because it is difficult to invade the market occupied by global firms or import specialized firms. In particular, they dominate the market based on large hospitals, so it is not easy for SMEs to grow just by implementing an import strategy [21].

The related diversification of a medical device firm had a positive effect on its sales ( $p<0.1$; Hypothesis 2-1 supported). These results are in line with previous studies that related diversification has a positive effect on corporate value [15]. Related diversification can reduce business risk because the more interrelated business units are, the more common resources that can be accessed there are; transaction costs can be reduced, and business units within the portfolio share common characteristics and are easy to manage $[15,66]$. In other words, related diversification enables the use of existing manpower, facilities, and distribution network, as well as the application of accumulated technologies. This is thought to be the result of the fact that most Korean medical device firms are SMEs and that small-volume production of various kinds in related fields has a positive effect on sales.

The unrelated diversification of a medical device firm had a positive effect on its sales $(p<0.1 ;$ Hypothesis $2-2$ supported). The results support previous studies that argued that unrelated diversification has a positive effect on a firm's growth and profitability [42]. One firm has a complementary relationship due to the difference in resource allocation patterns between departments or between business units. This can create a result that competitors cannot easily imitate [67]. It is also said that unrelated diversification has a positive impact on rapidly changing market environments because it can reduce resistance to inertia within a firm [68].

The R\&D intensity of a medical device firm had a positive effect on its sales $(p<0.01$; Hypothesis 3-1 supported). These results support previous findings that a firm's R\&D investment has a positive effect on its sales $[57,69]$. In this study, the time lag was set to 4 years, which reflects the long development period of medical device products. Considering not only development, but also clinical trials, certification, and approval, it would take a longer time to make a profit than other industries [3]. According to an additional analysis, there was no significant positive effect at time lag of less than 4 years (although not presented in Table 5, the effect of R\&D intensity was negative when the time lag was 1 to 3 years (1 year: $-2.12(0.52)^{* * *}, 2$ years: $-1.39(0.50)^{* * *}, 3$ years: $\left.-0.02(0.09)^{*}\right)$ ). Therefore, it was confirmed that it takes more than 4 years for technological innovation resulting from $R \& D$ investment to lead to sales in medical device industry [70].

Table 5. Regression results.

\begin{tabular}{|c|c|c|c|c|c|}
\hline & Model 1 & Model 2 & Model 3 & Model 4 & Model 5 \\
\hline Import & & $-2.22(2.28)$ & & & $-4.24(1.39)^{* * *}$ \\
\hline Rel_Div & & & $2.99(2.92)$ & & $3.11(1.73)$ * \\
\hline Unrel_Div & & & $4.61(3.60)$ & & $3.48(2.08)$ * \\
\hline $\ln \left(R_{n d} d_{\text {lag }}\right)$ & & & & $0.07(0.02)^{* * *}$ & $0.08(0.02)^{* * *}$ \\
\hline Pnd_dt & & & & $0.35(0.001)^{* * *}$ & $0.04(0.001)^{* * *}$ \\
\hline Size & $0.14(0.001)^{* * *}$ & $0.14(0.001)^{* * *}$ & $0.14(0.001)^{* * *}$ & $0.14(0.001)^{* * *}$ & $0.14(0.001)^{* * *}$ \\
\hline Age & $-0.33(0.14)^{* *}$ & $-0.32(0.14)^{* *}$ & $-0.36(0.14) *$ & $0.11(0.02)^{* * *}$ & $0.11(0.02)^{* * *}$ \\
\hline Listed & $-18.20(3.87)^{* * *}$ & $-18.00(3.87)^{* * *}$ & $-17.90(3.89)^{* * *}$ & $0.54(0.29)$ * & $0.55(0.29) *$ \\
\hline
\end{tabular}

The number of patent applications of a medical device firm had a positive effect on its sales ( $p<0.01$; Hypothesis 3-2 supported). These results support previous research findings that patents have a positive effect on sales growth [58]. In particular, the activities of patents acquired through research and development can be considered to have a direct effect on the business performance of the firm and positively contribute to sales. The number of 
patents identified in this research data differs by firm and year, and there are firms with no patents at all, but on average, patents are a factor influencing sales.

In Model 5 of Table 5, the number of employees had a positive effect on sales $(p<0.01)$. These results support previous studies that the number of employees significantly affects the performance of a firm [59]. Firm size measured by the number of employees is also proportional to the R\&D input and this can lead to improved productivity. However, since the increase in employment causes the increase in labor costs, it is necessary to maintain an appropriate balance according to the firm size [71].

The age of the firm had a positive effect on sales $(p<0.01)$. These results support previous studies that argued that the age of a firm affects its value or performance [60]. Because medical devices have a short service life, it is difficult to use them for a long time without continuously developing new products. High amounts of experience and knowhow can quickly respond to the needs of these markets. It is also judged to affect sales as it expands diversification and business models around existing distribution networks.

Whether firms are listed on KOSPI (Korea Composite Stock Price Index) or KOSDAQ (Korea Securities Dealers Automated Quotations) have a positive effect on sales $(p<0.1)$. This supports previous findings that listed firms and large firms have a positive relationship with capital structure and increase business performance [57,62]. In the case of listing on the KOSPI or KOSDAQ market, equity, sales, and market capitalization must meet the listing requirements. The listed firms are the result of concentrating on R\&D based on capital and stocks held and increasing sales with the launch of new products.

\section{Conclusions}

The present research was performed to analyze factors affecting the sales of Korean medical device manufacturers and derived a growth strategies suitable for the Korean context. The research targeted 440 medical device firms that received an approval from the MFDS and panel regression analysis was conducted. The results of this research confirmed that related and unrelated diversification, R\&D activity, and patents have a positive effect on sales, while import strategy has a negative effect. Considering that the Korean medical device industry is a relative latecomer and mainly composed of SMEs, it can provide implications to other latecomer countries under similar conditions.

The present research provides the following implications based on the results of the analysis. First, in order for the medical device import parallel business model to have a positive effect on business performance, an import business model using a differentiation strategy should be used. It is necessary to have an import strategy that can provide customers with differentiated products that are difficult for domestic manufacturers to produce. It is not competitive with products similar to those sold by overseas global medical device firms that have entered Korea, and competition is fierce with products of the same kind produced by domestic SMEs. It is also a good option to import core parts and consumables for medical devices that are difficult to manufacture and competitive in Korea. Imported medical devices fused with ICT technology can be a differentiated imported business model. For example, in vitro diagnostic medical devices to which ICT technology is applied have great potential to target niche markets for Asian firms such as Korea and China, which are less developed than in advanced countries.

Second, corporate managers of latecomer firms may consider diversification for their business growth. The medical device industry is suitable for diversification with multipleproduct and small-quantity production. Rather than producing a single item, diversifying the product even in a small amount can create synergy and improve sales [40]. For example, as electronic medical devices are designed according to common standard such as IEC 60601-1, they are easy to be diversified and the economies of scope may apply to them. However, if the size of the firm is too small, it should focus on a single specialized item to increase sales. Moreover, unrelated diversification was found to have a positive effect on sales. Large enterprises can overcome difficulties due to the efficiency of the resources they have inside, so they can enter new fields, but in the case of SMEs, excessively driving unrelated diversification 
without expertise may cause over-investment problems, and profitability may decrease due to unrelated diversification in existing specialized business sectors [37]. Therefore, in order for a firm to grow, it is desirable to improve technological and financial capabilities through related diversification and then switch to unrelated diversification.

Third, R\&D is an essential technological innovation factor for corporate growth. Corporate managers need to secure R\&D costs by making good use of the government R\&D support system to overcome the lack of internal financial capabilities. This is because venture capital markets in latecomer countries such as Korea or China are not mature enough, so investment funds are often not supplied in time. Research has found that firms that receive government $R \& D$ support benefits have a higher survival rate and have a positive effect on R\&D strength and technological innovation performance than those that do not [72]. In particular, corporate managers and doctors need to cooperate for joint research and development, and medical device patent applications also need to be submitted in collaboration with doctors' ideas and firm technical resources [1,2,73]. Korean medical device firms lack medical knowledge or clinical experience, so they are often turned away from doctors or hospital officials who are actual users, even after investing substantial time and R\&D expenses. From the medical device development stage, if a doctor participates, it is possible to develop a medical device that can be clinically applied and has a diagnostic value and therapeutic effect. It can also develop new technologies and generate revenue through continuous relationships with doctors if they acquire a license after patenting by sharing the ideas of engineers and doctors [1].

Although this research provides the above implications, there are also limitations. In a study that analyzes the causal relationship between variables such as sales, firm size, and corporate strategic behavior, as in this study, the endogeneity issue should be considered first. If there exist an endogeneity between variables, the estimation results of regression analysis are not due to causality, but simply a correlation. In addition, the analysis that does not take into account the existence of endogeneity may result in overestimation in a positive direction. In the field of econometrics, methods for removing endogeneity between variables have been developed, and representatively, instrumental variable method, dynamic model, and differential-in-difference (DID) are used [74]. In future research, it is necessary to compare and verify the robustness using above methods. Furthermore, firm size is a crucial factor that can also affect a firm's strategic behavior, so the endogeneity issue is likely to exist. In particular, there are various proxies for measuring the size of a firm. In addition to sales and the number of employees which are used in this study, there are various indicators such as total assets and market capitalization [75]. Therefore, future research should try to confirm whether there is endogeneity problem by using various methods.

The data used in this study are targeted at firms with detailed information such as sales, patent applications, and R\&D investment. Therefore, firms with insufficient data were excluded. This may make the dataset less representative. Moreover, dummy variables were used to examine the effects of diversification. In general, the Berry-Herfindahl Index (BHI) [76] or the Entropy index (EI) [77] is used as a variable related to diversification, but a simple form of the variable was used in this study due to the limited availability of the data. If detailed information on diversification is available for each firm, the impact of the diversification strategy will be able to be identified in more detail. Lastly, a firms' strategy can change dynamically according to their growth stage [78]. In a future study, a framework should be presented on how the strategies covered in this study will be implemented in detail as the latecomer grows.

Author Contributions: Conceptualization, K.Y. and K.S.; methodology, K.Y. and K.S.; validation, C.S.; formal analysis, K.Y.; investigation, K.Y.; resources, K.S.; data curation, K.S. and H.S.C.; writingoriginal draft preparation, K.Y.; writing-review and editing, C.S.; visualization, C.S.; supervision, C.S. and K.S.; project administration, K.S. All authors have read and agreed to the published version of the manuscript. 
Funding: This research received no external funding.

Data Availability Statement: The data presented in this study are available on request from the corresponding author. The data are not publicly available due to copyright issues.

Conflicts of Interest: The authors declare that there is no conflict of interest.

\section{References}

1. Chatterii, A.K.; Fabrizio, K.R.; Mitchell, W.; Schulman, K.A. Physician-industry cooperation in the medical device industry. Health Aff. 2008, 27, 1532-1543. [CrossRef] [PubMed]

2. Chatterji, A.K.; Fabrizio, K.R. Does the market for ideas influence the rate and direction of innovative activity? Evidence from the medical device industry. Strateg. Manag. J. 2014, 37, 447-465. [CrossRef]

3. Lee, M.J.; Yoon, Y.; Ryu, G.H.; Bok, H.S.; Yoon, K.C.; Park, S.W.; Lee, K.S. Innovative distribution priorities for the medical devices industry in the Fourth Industrial Revolution. Int. Neurourol. J. 2018, 22, 83-90. [CrossRef] [PubMed]

4. Tomaskova, H.; Maresova, P.; Penhaker, M.; Augustynek, M.; Klimova, B.; Fadeyi, O.; Kuca, K. The business process model and notation of open innovation: The process of developing medical instrument. J. Open Innov. Technol. Mark. Complex. $2019,5,101$. [CrossRef]

5. Ministry of SMEs and Startups. Technology Roadmap for SME 2018-2020; MSS: Daejeon, Korea, 2018; pp. 4-6.

6. Moultrie, J.; Sutcliffe, L.; Maier, A. A maturity grid assessment tool for environmentally conscious design in the medical device industry. J. Clean. Prod. 2016, 122, 252-265. [CrossRef]

7. EPO. Available online: https://www.epo.org/news-issues/news/2019/20190312.html (accessed on 10 May 2019).

8. Fitch Solutions. Worldwide Medical Devices Market Factbook; Fitch Solutions: New York, NY, USA, 2019.

9. Ministry Food and Drug Safety. Statistical Data for Medical Device Production and Import and Export in 2016; MFDS: Osong, Korea, 2017; pp. 2-19.

10. Kasahara, H.; Rodrigue, J. Does the use of imported intermediates increase productivity? Plant-level evidence. J. Dev. Econ. 2008, 87, 106-118. [CrossRef]

11. Wagner, R.J. International trade and firm performance: A survey of empirical studies since 2006. Rev. World Econ. 2012, 148, 235-267. [CrossRef]

12. Edwards, L.; Sanfilippo, M.; Sundaram, A. Importing and firm export performance: New evidence from South Africa. South Afr. J. Econ. 2018, 86, 79-95. [CrossRef]

13. Korea Health Industry Development Institute. Medical Device Industry Analysis Report; KHIDI: Osong, Korea, 2019; pp. 6-7.

14. Chen, C.J.; Yu, C.M.J. Managerial ownership, diversification, and firm performance: Evidence from an emerging market. Int. Bus. Rev. 2012, 21, 518-534. [CrossRef]

15. Galván, A.; Pindado, J.; De La Torre, C. Diversification: A value-creating or value-destroying strategy? Evidence from the Eurozone countries. J. Financ. Manag. Mark. Inst. 2014, 1, 43-64.

16. Vallejo-Torres, L.; Steuten, L.M.G.; Buxton, M.J.; Girling, A.J.; Lilford, R.J.; Young, T. Integrating health economics modeling in the product development cycle of medical devices: A Bayesian approach. Int. J. Technol. Assess. Health Care 2008, 24, $459-464$. [CrossRef] [PubMed]

17. Hirschle, A. Sehr gute Aussichten fur den Medizintechnikmarkt in Sudkorea; KORUM: Seoul, Korea, 2018 ; p. 73.

18. Schwab, K. The Fourth Industrial Revolution; CrownPub: New York, NY, USA, 2017.

19. Lee, D.; Lee, J. Testing on the move: South Korea's rapid response to the COVID-19 pandemic. Transp. Res. Interdiscip. Perspect. 2020, 5, 100111. [CrossRef]

20. Lee, M.J. Strategies for promoting the medical device industry in Korea: An analytical hierarchy process analysis. Int. J. Environ. Res. Public Health 2018, 15, 2659. [CrossRef] [PubMed]

21. Park, J.H.; Kim, E.D.; Shin, K.S. Developing an evaluation framework for selecting optimal medical devices. J. Open Innov. Technol. Mark. Complex 2019, 5, 64. [CrossRef]

22. Čirjevskis, A. Designing dynamically "signature business model" that support durable competitive advantage. J. Open Innov. Technol. Mark. Complex 2016, 2, 15. [CrossRef]

23. Shafer, S.M.; Smith, H.J.; Linder, J.C. The power of business models. Bus. Horiz. 2005, 48, 199-207. [CrossRef]

24. Coe, D.T.; Helpman, E. International R\&D spillovers. Eur. Econ. Rev. 1995, 39, 859-887.

25. Griliches, Z. The search for R\&D spillovers. Scand. J. Econ. 1992, 94, $29-47$.

26. Coe, D.T.; Helpman, E.; Hoffmaister, A.W. North-South R\&D spillovers. Econ. J. 1997, 107, 134-149.

27. Branstetter, L. Is foreign direct investment a channel of knowledge spillovers? Evidence from Japan's FDI in the United States. J. Int. Econ. 2006, 68, 325-344. [CrossRef]

28. Zhang, C.; Cavusgil, S.T.; Roath, A.S. Manufacturer governance of foreign distributor relationships: Do relational norms enhance the competitiveness in the export market? J. Int. Bus. Stud. 2003, 34, 550-566. [CrossRef]

29. Gilliland, D.I.; Bello, D.C.; Gundlach, G.T. Control-based channel governance and relative dependence. J. Acad. Mark. Sci. 2010, 38, 441-455. [CrossRef]

30. Obadia, C.; Bello, D.C.; Gilliland, D.I. Effect of exporter's incentives on foreign distributor's role performance. J. Int. Bus. Stud. 2015, 46, 960-983. [CrossRef] 
31. Ramanujam, V.; Varadarajan, P. Research on corporate diversification: A synthesis. Strat. Manag. J. 1989, 10, 523-551. [CrossRef]

32. Kwon, T.H. Related diversification and firm value. Korean J. Financ. Manag. 2019, 36, 33-62.

33. Ali, S.; Hashmi, S.H.; Mehmood, T. Corporate diversification and firm performance: An inverted U-shaped hypothesis. Int. J. Organ. Leadersh. 2016, 5, 381-398. [CrossRef]

34. Barton, S.L. Diversification strategy and systematic risk: Another look. Acad. Manag. J. 1988, 31, 166-175. [CrossRef]

35. Boz, I.T.; Yigit, I.; Anil, I. The Relationship between diversification strategy and organizational performance: A research intented for comparing Belgium and Turkey. Procedia Soc. Behav. Sci. 2013, 99, 997-1006. [CrossRef]

36. Teece, D.J. Towards an economic theory of the multiproduct firm. J. Econ. Behav. Organ. 1982, 3, 39-63. [CrossRef]

37. Meyer, M.; Milgrom, P.; Roberts, J. Organizational prospects, influence costs, and ownership changes. J. Econ. Manag. Strategy 1992, 1, 9-35. [CrossRef]

38. Markides, C. Consequence of corporate refocusing: Ex ante evidence. Acad. Manag. J. 1992, 35, 398-412. [CrossRef]

39. Stern, I.; Henderson, A.D. Within-business diversification in technology-intensive industries. Strateg. Manag. J. 2004, 25, 487-505. [CrossRef]

40. Helfat, C.E.; Eisenhardt, K.M. Inter-temporal economies of scope, organizational modularity, and the dynamics of diversification. Strateg. Manag. J. 2004, 25, 1217-1232. [CrossRef]

41. Kimseng, T.; Javed, A.; Jeenanunta, C.; Kohda, Y. Applications of fuzzy logic to reconfigure human resource management practices for promoting product innovation in formal and non-formal R\&D firms. J. Open Innov. Technol. Mark. Complex. 2020, 6,38 .

42. Hong, J.B.; Hwang, K.S. A study on the diversification of Korean manufacturing firms during 1986-1991. Korea Bus. Rev. 1997, 6, 493-511.

43. Hamrick, D.; Bamber, P. Pakistan in the Medical Device Global Value Chain; Duke University Global Value Chains Center: Durham, NC, USA, 2019.

44. Balkin, D.B.; Markma, G.D.; Gomez-Mejia, L.R. Is CEO pay high-technology firms related to innovation? Acad. Manag. J. 2000, 43, 1118-1129. [CrossRef]

45. Cefis, E.; Orsenigo, L. The persistence of innovative activities: A cross-counties and cross-sector comparative analysis. Res. Policy 2001, 20, 1139-1158. [CrossRef]

46. Cefis, E.; Marsili, O. Survivor: The role of innovation in firms' survival. Res. Policy 2006, 35, 626-641. [CrossRef]

47. Yun, J.H.J.; Won, D.K.; Park, K. Dynamics from open innovation to evolutionary change. J. Open Innov. Technol. Mark. Complex. 2016, 2, 7. [CrossRef]

48. Amit, R.; Zott, C. Business model design: A dynamic capability perspective. In The Oxford Handbook of Dynamic Capabilities; Teece, D.J., Leih, S., Eds.; Oxford University Press: Oxford, UK, 2016.

49. Kim, W.S.; Bae, H.J. The relationship between R\&D investment and cost of capital of IPO firms in KOSDAQ. Korea Int. Account. Rev. 2019, 84, 147-171.

50. Park, H.S. The Relationship between R\&D and Financial Distress. Ph.D. Thesis, Konkuk University, Seoul, Korea, August 2017.

51. Arakelian, L.; Kanai, N.; Dua, K.; Durand, M.; Cattan, P.; Ohki, T. Esophageal tissue engineering: From bench to bedside. Ann. N. Y. Acad. Sci. 2018, 1434, 156-163. [CrossRef] [PubMed]

52. Maresch, D.; Fink, M.; Harms, R. When patents matter: The impact of competition and patent age on the performance contribution of intellectual property rights protection. Technovation 2016, 57, 14-20. [CrossRef]

53. Ernst, H.; Conley, J.; Omland, N. How to create commercial value from patents: The role of patent management. $R D M a n a g$. 2016, 46, 677-690. [CrossRef]

54. Blind, K.; Edler, J.; Frietsch, R.; Schmoch, U. Motives to patent: Empirical evidence from Germany. Res. Policy 2006, 35, 655-672. [CrossRef]

55. Gelijns, A.; Rosenberg, N. The dynamics of technological change in medicine. Health Aff. 1994, 23, 28-46. [CrossRef]

56. Park, K.J. The Empirical Study on the Relationship between R\&D Expenditures and Firm's Performance in KOSDAQ Firms. Ph.D. Thesis, Hoseo University, Asan, Korea, February 2008.

57. Yoon, B.S.; Heo, H.Y. A study on the effects of investment of R\&D on a firm's performances: A Korean R\&D scoreboard in 2010. J. CEO Manag. Stud. 2011, 14, 109-131.

58. Kim, Y.H.; Jeong, B.K.; Yoon, J.H. A study on the effect of patent management activities on firm outcome: The case of Korean product manufacturing firms. J. Soc. Korea Ind. Syst. Eng. 2016, 39, 1-8. [CrossRef]

59. Silverman, B.S.; Nickerson, J.A.; Freeman, J. Profitability, transactional alignment, and organizational mortality in the US trucking industry. Strateg. Manag. J. 1997, 18, 31-52. [CrossRef]

60. Kim, J.E. Analysis of financial ratios of domestic manufacturing firms by size and age: Korea Standard Industrial Classification 9th main category manufacturing. Korean Corp. Manag. Rev. 2017, 24, 57-83.

61. Freeman, J.; Carroll, G.R.; Hannan, M.T. The liability of newness: Age dependence in organizational death rates. Am. Sociol. Rev. 1983, 48, 692-710. [CrossRef]

62. Kurshev, A.; Strebulaev, I.A. Firm size and capital structure. Q. J. Financ. 2015, 5, 1550008. [CrossRef]

63. Petit, M.L.; Sanna-Randaccio, F. Endogenous R\&D and foreign direct investment in international oligopolies. Int. J. Ind. Organ. 2000, 18, 339-367. 
64. Uotila, J.; Maula, M.; Keil, T.; Zahra, S.A. Exploration, exploitation, and financial performance: Analysis of S\&P 500 corporations. Strateg. Manag. J. 2009, 30, 221-231.

65. Juhro, S.M.; Narayan, P.K.; Iyke, B.N.; Trisnanto, B. Is there a role for Islamic finance and R\&D in endogenous growth models in the case of Indonesia? Pac. Basin Financ. J. 2020, 62, 101297.

66. Benito, D.; Guerras, L.; Zuñiga, J. Four decades of research on product diversification: A literature review. Manag. Decis. 2012, 50, 325-344. [CrossRef]

67. Harrison, J.S.; Hitt, M.A.; Hoskisson, R.E.; Ireland, R.D. Synergies and post acquisition performance: Differences versus similarities in resource allocations. J. Manag. 1991, 17, 173-190. [CrossRef]

68. Cho, Y.S. The effect of business diversification on a firm's performance, depending on its dynamic capabilities and market dynamism. J. Manag. Strateg. 2013, 4, 1.

69. Lee, J.H.; Seo, C.S.; Lee, C.G. A study on the effect of investment of R\&D on firm's performance in the medical device industry. J. Korea Manag. Eng. Soc. 2017, 22, 89-105.

70. Artz, K.W.; Norman, P.M.; Hatfield, D.E.; Cardinal, L.B. A longitudinal study of the impact of R\&D, patents, and product innovation on firm performance. J. Prod. Innov. Manag. 2010, 27, 725-740.

71. Hamermesh, D.S. Do Labor Costs Affect Companies' Demand for Labor? Available online: https://wol.iza.org/articles/dolabor-costs-affect-companies-demand-for-labor/long (accessed on 10 May 2019).

72. Shin, K.S.; Choy, M.K.; Lee, C.; Park, G.N. Government R\&D subsidy and additionality of biotechnology firms: The case of the South Korean biotechnology industry. Sustainability 2019, 11, 1583.

73. Chatterji, A.K. Spawned with a silver spoon? Entrepreneurial performance and innovation in the medical device industry. Strateg. Manag. J. 2009, 30, 185-206. [CrossRef]

74. Li, F. Endogeneity in CEO power: A survey and experiment. Invest. Anal. J. 2016, 45, 149-162. [CrossRef]

75. Dang, C.; Li, Z.F.; Yang, C. Measuring firm size in empirical corporate finance. J. Bank. Finance. 2018, 86, 159-176. [CrossRef]

76. Berry, C.H. Corporate growth and diversification. J. Law Econ. 1971, 14, 371-383. [CrossRef]

77. Jacquemin, A.P.; Berry, C.H. Entropy measure of diversification and corporate growth. J. Ind. Econ. 1979, 27, 359-369. [CrossRef]

78. Song, C.; Shin, K. Business model design for latecomers in biopharmaceutical industry: The case of Korean firms. Sustainability 2019, 11, 4881. [CrossRef] 